\title{
Point of Purchase or Point of Frustration? Consumer Frustration Tendencies and Response in a Retail Setting
}

\section{Authors: Eric Van Steenburg, Nancy Spears, and Robert O. Fabrize}

This is the peer reviewed version of the following article: citation below, which has been published in final form at http://dx.doi.org/10.1002/cb.1440. This article may be used for noncommercial purposes in accordance with Wiley Terms and Conditions for Self-Archiving.

Van Steenburg, Eric, Nancy Spears, and Robert O. Fabrize. "Point of Purchase or Point of Frustration? Consumer Frustration Tendencies and Response in a Retail Setting." Journal Consumer Behavior 12, no. 5 (September 2013): 389-400. doi:10.1002/cb.1440.

Made available through Montana State University's $\underline{\text { ScholarWorks }}$ scholarworks. montana.edu 


\title{
Point of purchase or point of frustration? Consumer frustration tendencies and response in a retail setting
}

\author{
ERIC VAN STEENBURG ${ }^{1 *}$, NANCY SPEARS ${ }^{2}$ and ROBERT O. FABRIZE ${ }^{3}$ \\ ${ }^{1}$ Department of Marketing, College of Business, James Madison University, Harrisonburg, VA 22807, USA \\ ${ }^{2}$ Department of Marketing \& Logistics, College of Business, University of North Texas, PO Box 311396, Denton, TX 76203-5017, USA \\ ${ }^{3}$ International Business \& Marketing Department, California State Polytechnic University, Pomona, 3801 West Temple Ave., Pomona, CA \\ 91768, USA
}

\begin{abstract}
The research applies precepts from frustration theory to investigate frustration when a goal is blocked in a consumer context. Predictions are derived, and two studies are designed to investigate the goal-directed sequence following a blocked goal and the role of individual differences in frustration tolerance in a retail checkout encounter. The findings of the research suggest that when the goal of retail checkout is blocked, consumers adopt either adaptive or maladaptive resolution strategies. Those who take an adaptive approach return to goal-seeking behaviour, whereas those following the maladaptive path initially resolve their frustrations through resignation. That initial resolution strategy of resignation then produces a second wave of new blocks to goal attainment (helplessness, anger and self-preoccupation). Subsequently, the second wave of blocks is countered with a second set of resolution strategies (alteration, substitution, abandonment with acceptance or abandonment with suffering). The research findings also reveal that consumer frustration responses are associated with internal versus external blame and with social surroundings or who is watching the frustrating event unfold. The results likewise indicate that attitude toward the company and repatronage intentions are influenced by social surroundings and by individual differences in frustration tolerance (fairness, entitlement, gratification and achievement). Copyright (C) 2013 John Wiley \& Sons, Ltd.
\end{abstract}

\section{INTRODUCTION}

Although practically everyone has experienced at least one frustrating experience as a consumer, little is known about the process that each of us goes through when confronted with frustration-despite the fact that frustration is an important motivator of consumer behaviour (Wetzer et al., 2007). Why do individuals react differently to a frustrating situation? What tendencies guide consumer frustration response? The following research attempts to understand consumption behaviour through the theoretical lens of frustration in an effort to answer questions like these and to help managers better deal with frustrated customers.

Freud (1958) described frustration in terms of barriers to goal attainment and internal obstacles that block satisfaction in reaching a goal. Frustration occurs when a negative outcome results when a positive outcome is desired (Roseman, 1991) because situational events are obstructive to goal attainment, delay goal attainment or require additional effort for goal attainment (Scherer, 2001). The frustrating situation, in conjunction with individual psychological characteristics, determines resulting behaviour (Freud, 1958) and the response pattern adopted. Consumers who perceive the situation to be unfair or out of their control-because of the barriers to goal attainment rather than the failure to attain the goal—are more likely to experience frustration (Guchait and Namasivayam, 2012). Conversely, consumers who achieve their expected level of payoff, service or satisfaction will not experience frustration in the situation (Wetzer et al., 2007).

Despite these insights, questions remain about frustration responses in a consumer context. Thus, the central purpose of

\footnotetext{
* Correspondence to: Eric Van Steenburg, Department of Marketing, College of Business, James Madison University, Harrisonburg, VA 22807, USA.

E-mail: eric.v@att.net
}

the present research is to serve as an early-stage investigation into consumer frustration when goal attainment is blocked. This central purpose responds to the call of Tuzovic (2010) for research that investigates the relationships between frustration incidents and subsequent dysfunctional customer behaviour. To accomplish our research goal, three objectives are presented. First, the research draws on precepts from frustration theory (Dollard et al., 1939; Barker et al., 1941; Block and Martin, 1955; Amsel, 1958, 1992; Shorkey and Crocker, 1981; Harrington 2005a, 2005b) to develop predictions. Second, the study aims to expand the current understanding of frustration (Shorkey and Crocker, 1981; Strauss et al., 2005; Guchait and Namasivayam, 2012) by investigating individual differences in frustration tolerance when goals are blocked. Finally, the research seeks to contribute to our understanding of consumer attitudes toward retailers by studying consumer frustration in a retail checkout context (Jones and Reynolds, 2006).

\section{BACKGROUND}

Recent efforts to model frustration have identified three core elements: (i) the frustrating incident; (ii) the frustration sensation; and (iii) the resulting frustration behaviour (Strauss et al., 2005; Tuzovic, 2010). It is the behavioural element that is the focus of the present research. Frustration is an obstacle to attainment of an expected goal (Anderson and Buschman, 2002) when goal-directed behaviour and anticipatory goal responses comingle to create an expectation that is thwarted (Berkowitz, 1989), resulting in unpleasantness, uncertainty and a strong desire to attend to the situation (Smith and Ellsworth, 1985) via a frustration behaviour sequence. The objective of the individual is to eliminate the negative feeling elicited by the frustration sensation (Berkowitz, 1989) and return to goal-directed behaviour. 
Early frustration research tried to establish links between frustration and either aggressive behaviour (Dollard et al., 1939) or regressive behaviour (Barker et al., 1941). They defined frustration as 'an interference with the occurrence of an instigated goal response at its proper time in the behaviour sequence' (Dollard et al., 1939, p. 7). That is, an instigator-an antecedent condition such as a thwarted motive or deprivation-must be present to create the sense of frustration. Should goal attainment be blocked, needs are not met, leading to motivational-emotional state that often includes frustration (Verhallen, 1982; Coleman, 2001; Pincus, 2004). According to Amsel (1992), frustration is a learned state that is permanent, for that situation. When individuals are presented with situations that block them from attaining a goal, initial resolution strategies are developed in response to overcome the frustration (Dollard et al., 1939).

Individuals experiencing frustration typically attempt their preferred method for problem solving more often, before abandoning their efforts, than those who were not frustrated (Maier and Feldman, 1948), demonstrating that responses are related to reinforced behaviour and coping mechanisms (Amsel, 1958; 1962; Wagner, 1963; Hill, 1968). This behaviour is designed to prevent recurrence of the frustration (Strauss et al., 2005). Additional responses include persistence (Nation and Massad, 1978; Nation and Woods, 1980; Amsel, 1992), helplessness (Rosellini and Seligman, 1975; Levis, 1976; Maier and Seligman, 1976) and aggression (Berkowitz, 1989; Tedeschi and Felson, 1994). Individual responses allow for a release of stress due to feelings of distress experienced in dissatisfying situations (Stiles, 1987). Desire to vent frustration is the most common response to a situation where goal attainment is blocked (Nyer, 1997), yet the behavioural response sequence in relation to goal attainment while experiencing frustration remains unexplored.

Initially, Shorkey and Crocker (1981) identified three frustration-elicited adaptive responses: (i) a strategy to overcome the obstacle denying the individual from reaching the goal; (ii) a strategy to circumvent the obstacle; and (iii) a strategy to avoid the obstacle. In general, individuals choosing adaptive response strategies exhibit a facilitating process aimed at problem solving to address the frustration object. Conversely, maladaptive response patterns work through a more affect-laden process addressing the stress, leading to any of four maladaptive response strategies: (i) aggression toward the obstacle; (ii) regression, or going back to a less mature behaviour; (iii) fixation or repetitive behaviour; and (iv) resignation leading to inertia or apathy (Shorkey and Crocker, 1981). Frustration behaviour has also been described as falling into one of three responses: (i) protest; (ii) intensification of effort; and (iii) avoidance (Strauss et al., 2005). Although useful for illuminating distinct categories of response strategies, what is known about frustration does not shed any light on the goal-directed sequence that follows the selection of an initial frustration resolution strategy.

\section{HYPOTHESES-STUDY 1}

Extensive research in exchange theory has demonstrated that individuals experience negative emotions when they perceive the situation to be unfair and the outcome to fall short of their expectations (Lawler, 2001; Turner and Stets, 2006) and result in certain behavioural responses (Yi and Baumgartner, 2004). Specifically, when 'payoff levels' are not met, individuals experience frustration (Guchait and Namasivayam, 2012). Therefore, placing individuals in an exchange setting, such as a retail checkout situation, and blocking them from obtaining their goal should result in a frustrating experience.

Study 1 was developed to accomplish three objectives: (i) identify dimensions of adaptive and maladaptive response strategies adopted by consumers; (ii) test for interdependence between these identified dimensions and the source of blame for the frustrating circumstance; and (iii) determine if individual differences in frustration tolerance among consumers predict felt frustration in a retail checkout context. To accomplish these objectives, an experiment was developed to simulate a frustrating situation.

Frustration responses are associated with the source of blame for the frustration event (Gelbrich 2009; Roseman, 1991; Rosenzweig, 1934; Smith and Lazarus, 1990) and influenced by two antecedent factors: (i) intraindividual, or individual differences that effect cognitive and affective responses to frustrating situations; and (ii) situational, or the social environment and the specific conditions related to a particular event that caused the perceived frustration. Thus, frustration strategies in the context of a frustrating checkout scenario should associate with the source of blame along adaptive or maladaptive frustration responses (Shorkey and Crocker, 1981).

Hla: Consumers' adaptive frustration response strategies are associated with the source of blame (external or internal).

$H 1 b$ : Consumers' maladaptive frustration response strategies are associated with the source of blame (external or internal).

Maladaptive response strategies follow a debilitative process and hinder goal pursuit (Alpert and Haber, 1960), whereas negative attainment of goals decreases desire for achievement and any associated behaviour related to goal attainment (Weiner, 1986). If an individual uses an affectladen maladaptive approach, response strategies impede progress toward the goal, compound the original block and create additional, new blocks (Shorkey and Crocker, 1981). These newly created blocks further impede progress toward goal attainment. This process is identified as laddering, in which individuals are taken beyond their intended goal and must make adjustments to their goal-attainment process as situations evolve (Gutman, 1997). When experiencing a frustrating event, consumers must develop new actions, or sequences of actions, to reach their goal. 
$H 2$ : In the case of a maladaptive response, new blocks created by consumers are associated with the source of blame (external or internal).

\section{RESEARCH DESIGN}

A 33-item paper-based questionnaire was developed to capture cognitive responses to an imaginary frustrating retail situation at final checkout and a scenario-based manipulation for source of blame (external vs. internal) to test H1a, H1b and H2. The Frustration Discovery Scale (FDS) was used to measure individual differences in frustration among study participants (Harrington, 2005b). Participants were presented one of two scenarios designed to elicit blame toward either the retailer or themselves. The scenario for external blame read:

Imagine you've gone to the grocery store right before dinner time to pick up something to eat that night. You go to the self-service checkout line because you only have four items and you're in a hurry. You scan your items and try to pay, but the credit card machine won't accept the one credit card you have with you. You have no checks or cash.

The scenario for internal blame was similar, except the ending read: 'You scan your items and try to pay, but then realize you left your credit cards and checkbook at home. You have no cash.'

Following the scenarios, cognitive responses were generated by asking participants 'What would you do next?' and 'Why would you do this?' Participants then responded to the FDS via a seven-point Likert scale $(1=$ strongly disagree, $7=$ strongly agree $)$, before providing demographic information . The instrument concluded with two manipulation checks that asked respondents to rate their level of frustration and how much blame they would place on themselves for what happened. A sample of 110 undergraduate students from a large public university in the Southwestern USA participated in spring 2010 in exchange for class credit. Mean age was 22.6 years $(S D=2.08)$ and men comprised 59.1 per cent of respondents.

\section{DATA ANALYSIS AND FINDINGS}

Analysis of the manipulation check revealed that it worked for both the level of frustration ( $p$-value $<0.001, M=3.71$, $S D=1.78)$ and blame $(p<0.001, M=4.44, S D=2.25)$. Because the first objective was to identify adaptive and maladaptive response strategies, cognitive responses by participants were examined closely by a panel of three judges (Bernard and Ryan, 2010). Each judge reviewed every response and assessed a temporary category for labelling purposes to identify themes present in the data (Bernard and Ryan, 2010).

The coding of cognitive responses to 'What would you do next?' showed that of the 110 respondents, 71.8 per cent $(n=79)$ chose an adaptive response and 28.1 per cent $(n=31)$ chose a maladaptive response. Adaptive responders were judged to be participants who displayed a facilitative process and identified other methods to obtain their goal. Maladaptive responders were judged to be participants who exhibited a debilitative process that impeded successful goal attainment.
Three adaptive strategies were identified: (i) overcome (persist by actively pursuing the original goal); (ii) circumvent (identify and pursue alternative satisfactory goals); and (iii) avoidance (avoid the blocks and the goal altogether). In each case, respondents returned to goal-seeking behaviour, supporting previous research (Amsel, 1958, 1962; Butterfield, 1964; Shorkey and Crocker, 1981). This was confirmed by examining the second question asked-'Why would you do this?'- to which those who responded adaptively to the frustration continued toward their goal.

Go to the regular line./To see if the other machine would accept my card.

Proceed to the next available line with an actual human checker./It would be irritating, but not enough to leave the store.

I would call my boyfriend and ask him for my card number and type it manually, or just order pizza./It's what I've done in the past.

I would set my things aside, let the cashier know and ask if she would keep it until I came back./Because I plan to make a quick trip home and don't want to have to reshop.

For the maladaptive process, results of coding revealed that a resignation strategy - a lost motivation to perform and complete the goal-directed behaviour-was used by every respondent, helping verify that it is the most common maladaptive response (Shorkey and Croker, 1981). The coding of cognitive responses for the maladaptive group to 'Why would you do this?' was designed to reveal the presence of any newly created blocks toward achieving the checkout goal. Three dimensions emerged from the analysis: (i) helplessness; (ii) anger (including impatience); and (iii) self-preoccupation (includes self-presentation, self-preservation, self-recrimination and self-advancement). This parallels Gelbrich's (2009) findings that linked frustration, anger and helplessness in terms of coping strategies.

Helplessness occurs when individuals perceive a low potential to cope with an aversive situation (Lazarus, 1991). Respondents creating the helplessness block $(n=12)$ expressed a lack of options in achieving their goal. They examined the situation, determined there was little-to-nothing they could do and expressed a desire to abandon their goal-attainment efforts. According to learned helplessness (Maier and Seligman, 1976), an individual has developed a learned response to outcomes they deem uncontrollable, whereas feelings of helplessness are linked to frustration experiences (Rosellini and Seligman, 1975).

I would leave because there was nothing else I could do about it.

With no money I can't buy anything so the only thing to do is leave.

Respondents who exhibited anger as a secondary block $(n=7)$ appeared quick to lose patience as a result of their frustration and reacted with hostility toward the entity they perceived to be the cause. Wetzer et al. (2007) found that 
although frustration and anger were related conceptually, they differed in their focus because frustration leads to a focus on the negative outcome, whereas anger leads to a focus on blaming others. The anger dimension uncovered here is akin to extrapunitive response behaviour (Rosenzweig, 1934) and provides support for findings that frustration intolerance is associated with anger (Martin and Dahlen, 2004).

I will be upset with my bank card if that is the problem, but knowing for sure my card is good will make me upset with the card machine in the store.

I would go to another line first to see if an employee could help, but then after that I would get frustrated at their business.

Respondents who create a self-preoccupation secondary block $(n=12)$ were most concerned with how they fared as a result of the frustrating situation and supports the idea that frustration can lead to a preoccupation with the self (Maier and Ellen, 1959). Subcomponents of the self-preoccupation dimension include self-presentation, self-recrimination, self-aggression and self-advancement. Those who exhibited self-presentation were worried about how they looked to others in the store, whereas respondents who showed self-recrimination often tried to figure out what they had done wrong and how they were to blame.

Ask a person in charge of the self-service registers to cancel the transaction and explain the reason. And come back some other time to be courteous to the people behind me and also the employee won't think that I was just being rude.

I would shrug with frustration because I was stupid enough to forget my money and hurriedly tell the clerk I don't want the stuff so that I could get out of the store quickly.

A $\chi^{2}$ test of association between adaptive response strategies and source of blame was significant $\left(\chi^{2}=22.11, d f=2\right.$, $p=0.00$ ), lending support for H1a (Table 1). H1b was not tested because only one maladaptive response (resignation) was identified. The $\chi^{2}$ for the asymptotic test of association for maladaptive block to goal attainment by source of blame was significant $\left(\chi^{2}=6.68, d f=2, p=0.035\right)$, supporting $\mathrm{H} 2$. Although cell frequencies above 5 are considered adequate and up to 20 per cent of cell frequencies can have frequencies less than 5 without producing problems (Freund and Wilson, 1993), this test of association for source of blame against each secondary block had more than 20 per cent sparse cells. Therefore, we conducted an additional test (Fisher's exact test) that requires no assumptions about cell counts. This test computes the exact probability of finding a unique table and derives a $p$-value by generating an entire registry of tables that are more contradictory to the null than the table in

Table 1. Adaptive response by source of blame (Study 1 )

\begin{tabular}{lcc}
\hline Adaptive response & Internal blame & External blame \\
\hline Overcome & $0(0.0 \%)$ & $18(43.9 \%)$ \\
Circumvent & $29(76.3 \%)$ & $16(39.0 \%)$ \\
Avoid & $9(23.7 \%)$ & $7(17.1 \%)$ \\
\hline
\end{tabular}

Note: $\chi^{2}=22.11, d f=2, p=0.00$.
Table 2. New maladaptive block to goal attainment by source of blame (Study 1)

\begin{tabular}{lcc}
\hline Maladaptive block & Internal blame & External blame \\
\hline Helplessness & $5(35.7 \%)$ & $7(41.2 \%)$ \\
Anger & $6(42.9 \%)$ & $1(5.9 \%)$ \\
Self- preoccupation & $3(21.4 \%)$ & $9(52.9 \%)$ \\
\hline
\end{tabular}

Note: $\chi^{2}=6.68, d f=2, p=0.051$ (Fisher's exact test).

question (Baglivo et al., 1988). Like the asymptotic test of association, the result of Fisher's exact test was also significant ( $p=0.051$; Table 2). Results suggest that the frustration responses of consumers are associated with source of blame, and individual differences in frustration tolerance among consumers may be related to felt frustration at checkout. Additionally, the findings revealed the presence of all three adaptive resolution strategies adopted by consumers.

\section{HYPOTHESES—STUDY 2}

Findings from Study 1 suggested that when consumers blame the retailer, choice of the affect-laden maladaptive-resignation resolution strategy is slightly more often associated with a sense of self-preoccupation or how they look to others around them. This may be a function of the fact that frustration can be triggered when individuals place blame on the situation (Roseman 1991), which, in Study 1, was at a retail establishment. In addition, consumers often experience frustration following service failure (Nyer, 2000; Laros and Steenkamp, 2005), which fosters support-seeking behaviour (Menon and Dubé, 2007). However, because participants in this study may have associated blame for the retailer as a consequence of the situation, rather than blaming the situational sources, a second study was developed to keep blame focused and add relevance to our current understanding of individual differences in frustration toleration among consumers. That is, Study 2 manipulates the social environment in terms of who is present with the respondent, while holding source of blame (external, i.e. the retailer) constant.

Sociological and cultural influences determine frustration response in certain individuals (Maier and Ellen, 1959; Amsel, 1992). It is possible, then, that the existence and/or type of people observing the individual experiencing frustration affects their frustration response. Because one's prior experiences affect his or her drive toward goal attainment (Amsel, 1958; 1992; Strauss et al., 2005), it is also plausible that familiarity is related to frustration response. Therefore, the external aspects of the frustrating situation should affect response behaviour.

H3: Secondary blocks (helplessness, anger and selfpreoccupation) in a retail checkout context are associated with a consumer's surrounding social environment.

Although secondary blocks may hinder the goal-directed sequence and goal attainment, individuals ultimately seek to resolve these blocks and move forward (Shorkey and Crocker, 1981). Therefore, the secondary blocks consumers create must be resolved with secondary resolution strategies. In addition, if sociological influences can determine frustration response behaviour (Maier and Ellen, 1959; 
Amsel, 1992), then goal resolution is related to the frustrating situation (Shorkey and Crocker, 1981).

H4: Secondary blocks (helplessness, anger and selfpreoccupation) derived from maladaptive frustration responses are associated with a consumer's secondary goal resolution strategies.

H5: Secondary goal resolution strategies adopted by consumers are associated with the surrounding social environment.

Of the six factors within the FDS, four are related to an individual's expectation of reward (entitlement, achievement, gratification and fairness) and two are related to what one is unable to or indisposed to endure (discomfort intolerance and emotional intolerance). Because frustration 'appears if individuals do not reach goals that were thought as feasible or do not get rewards that were pledged' (Strauss et al., 2005, p. 234), Study 2 will only include the aforementioned FDS factors related to reward. An examination of these four factors follows.

\section{Entitlement}

Entitlement is a perceived right to demand (Hurst and Good, 2009) where privileges become rights (Wellner, 2004). It is the expectation that reward is not necessarily based on performance (Harvey and Martinko, 2009) and is instead based on an unbalanced perception of reciprocity (Naumann et al., 2002) in which individuals expect preferential treatment in social settings (Snow et al., 2001).

\section{Fairness}

Consumers are more likely to experience frustration when a situation is not controllable and they believe the exchange to be unfair (Van den Bos et al., 1997). In modelling the psychological processes that take place within a consumers' evaluation of an exchange, Guchait and Namasivayam (2012) found that frustration acts as a mediator and can explain the relationship between perceptions of control, fairness and satisfaction. In situations where expected fairness norms are violated, individuals are more likely to have stronger affective reactions (Van den Bos, 2001). And because Harrington (2005a) found that some items referring to fairness also loaded on entitlement, it is expected that consumers will react similarly to a frustrating situation in terms of fairness as they do for entitlement.

\section{Gratification}

A preference for immediate gratification leads one to overindulge in activities with immediate rewards and delayed costs, and overconsume basic goods (O'Donoghue and Rabin, 2000). Gratification is a competency rather than an orientation toward motivational expression (Funder and Block, 1989) and therefore influences behaviour in contexts where reward is immediately available (Smith et al., 1972). Because Harrington (2005a) found that some items referring to gratification also loaded on entitlement, it is expected that consumers will react similarly to a frustrating situation in terms of gratification as they did for entitlement.

\section{Achievement}

Need for achievement is the motive to succeed by doing things better, with surpassing standards of excellence (Borges et al., 2010). But because achievement is based on an extended temporal approach to goal attainment, a retail checkout setting is temporally constrained and therefore should not allow for achievement characteristics to affect behaviour.

In addition, product purchase and store patronage by consumers is also influenced by socialization, self-discrepancy and feelings of accomplishment (Noble et al., 2009), whereas frustration has also been found to help explain repatronage intentions (Soderlund, 2003). Therefore, it is expected that social situation will influence both attitude toward the company and repatronage intention. In concert with the four FDS factors, the following are proposed:

H6: Attitude toward the company and repatronage intention will be (i) more positive for consumers with high levels of entitlement facing a frustrating situation alone than those with low levels of entitlement; (ii) less positive when with people they do not know; and (iii) slightly less positive when with people they do know.

H7: Attitude toward the company and repatronage intention will be (i) more positive for consumers with high levels of fairness facing a frustrating situation alone than those with low levels of fairness; (ii) less positive when with people they do not know; and (iii) slightly less positive when with people they do know.

H8: Attitude toward the company and repatronage intention will be (i) more positive for consumers with high levels of gratification facing a frustrating situation alone than those with low levels of gratification; (ii) less positive when with people they do not know; and (iii) slightly less positive when with people they do know.

H9: Attitude toward the company and repatronage intention will not be significantly different for consumers with high levels of achievement facing a frustrating situation than those with low levels of achievement in any social situation.

\section{RESEARCH DESIGN}

An attempt was made in Study 2 to force respondents to focus on the goal at hand within the constraints provided. To accomplish this, a 58-item online questionnaire was developed that relied on imaginary scenarios to manipulate the social environment (alone, with people they did not know, with people they did know), asked open-ended questions for qualitative analysis and included scales measuring attitude toward the company (Goldsmith et al., 2001), repatronage intention (Bolton et al., 2000) and frustration tolerance (Harrington, 2005b) as dependent variables. The first scenario in which respondents were alone read: 
Imagine you have gone to the drive through of a fast food restaurant to get something to eat in the few minutes you have before you have to be at work. There are seven cars ahead of you in line, and you're afraid you might end up being late. But you're hungry and have no other choice. When you finally get to the window to pay and pick up your food, the cashier tells you their credit card machine is broken and they're only able to accept cash. You have no money on you and no time to go anywhere else.

The second scenario, in which the participant was with people they did not know was similar, except the first sentence read:

Imagine you and two brand new co-workers have gone to the drive through of a fast food restaurant to get something to eat in the few minutes you have before you have to be at work.

The third scenario, in which respondents were with people they did know, was similar, but inserted 'two of your closest friends' in place of 'two brand new co-workers' in the first sentence.

Following the scenarios, the respondents were asked 'Based on the situation you just read, what would you do next?' and 'Based on your previous answer, why would you do this?' They were then asked to rank order how they felt in this situation based on the three maladaptiveresignation secondary blocks (helplessness, anger and selfpreoccupation) from Study 1. Follow-up questions were asked that stated, for example, "You rated "angry with someone or something" as your top feeling. Rate how angry you would feel' after which participants responded via a seven-point Likert scale $(1=$ not at all, $7=$ very $)$. Two more follow-up questions were presented for the block responses they ranked second and third. A manipulation check followed before respondents answered the items of the FDS, after which they responded to the scales measuring attitude toward the company and repatronage intention scale. Next, manipulation check questions measuring level of frustration and internal versus external source of blame were followed by demographics.

A sample of 180 students from a large Southwestern US public university completed the online questionnaire in fall 2010 in exchange for course credit. Of the respondents, 24 did not complete the questionnaire, and three were eliminated for failing to follow directions, resulting in a sample size of 153 that had mean age 24.5 years $(S D=4.64)$ with 48.4 per cent men $(n=74)$.

\section{DATA ANALYSIS AND FINDINGS}

Data analysis of the manipulation check revealed the manipulation worked for level of frustration $(p<0.001$, $M=5.01, S D=1.53)$, source of blame $(p<0.001, M=5.0$, $S D=1.80)$ and social environment $(p<0.001)$. A $\chi^{2}$ test of association (Table 3 ) to find whether secondary blocks that impede goal attainment are associated with social surroundings was significant $\left(\chi^{2}=9.14, d f=4, p=0.057\right)$
Table 3. New maladaptive block to goal attainment by social environment (Study 2)

\begin{tabular}{lccc}
\hline $\begin{array}{l}\text { Maladaptive } \\
\text { block }\end{array}$ & Alone & $\begin{array}{c}\text { With others: } \\
\text { unknown }\end{array}$ & $\begin{array}{c}\text { With others: } \\
\text { known }\end{array}$ \\
\hline Helplessness & $18(42.9 \%)$ & $15(29.4 \%)$ & $28(44.4 \%)$ \\
Anger & $20(47.6 \%)$ & $16(51.0 \%)$ & $19(30.2 \%)$ \\
$\begin{array}{l}\text { Self- } \\
\text { preoccupation }\end{array}$ & $4(9.5 \%)$ & $10(19.6 \%)$ & $16(25.4 \%)$ \\
\hline
\end{tabular}

Note: $\chi^{2}=9.14, d f=4, p=0.057$

and supports $\mathrm{H} 3$ that sociological influences can determine frustration response (Maier and Ellen, 1959; Amsel, 1992).

Cognitive responses were coded by a three-judge panel, which assessed a temporary category for labelling purposes (Bernard and Ryan, 2010). Following review of all responses to the question 'What would you do next?', four types of secondary resolution strategies were identified: (i) goal alteration; (ii) goal substitution; (iii) goal abandonment with acceptance; and (iv) goal abandonment with self-suffering.

With goal alteration $(n=64)$, respondents attempted to find opportunities to complete the goal by inserting a replacement for the initial goal (Berkowitz, 1989). Despite respondents' thoughts of continuing on in their quest to attain their goal, they initially displayed a maladaptive-resignation resolution strategy with the situation (e.g. leaving that particular store) before trending toward goal alteration.

There isn't much else you can do because you don't have cash. The best thing to do is try to go somewhere near to get something to eat.

I would most likely be upset, but not at the clerk. The situation would just anger and annoy me. Since we had limited time to get our lunch and return to work. The drive-through took up all of our time. I would hope that by returning to work I would be able to find something to eat in my desk or a vending machine.

Those who showed signs of goal substitution $(n=16)$ were not looking for an exact replacement to the initial goal but rather substituting something completely different for the original objective. In most cases, the ability to vent one's frustration at the store provided a substitutive option (Nyer, 1997), known as aggressive displacement (Dollard et al., 1939), in which the individual transfers his or her anger to another object.

I would say to the person in the window, 'Go put a sign up outside or at least on the menu, so that I could have known before wasting my time in line waiting to find this out. Now I'm going to have to go to work hungry ... geez!'

I would probably ask to see a manager and ask why they didn't think to put up any signs at the first menu to tell customers that credit card machines are down. I would then ask if there was a way to get my food compt (sic). If not, I would probably drive off because I had to be back into work. 
Finally, respondents exhibited two types of goal abandonment following initial resignation-either with acceptance or with suffering. Because maladaptive responses diminish problem-solving abilities (Dollard et al., 1939; Maier, 1956; Shorkey and Crocker, 1981), individuals may believe no options exist for goal attainment or may simply want to vent their frustration with no expectation nor desire to receive anything from the firm (Mattila and Wirtz, 2004). Those abandoning with acceptance $(n=64)$ were resigned to the fact that nothing could affect or change the situation. Therefore, they simply accepted the outcome and did not move beyond initial resignation. Those abandoning with suffering $(n=9)$ exhibit characteristics of martyrdom. The secondary resolution strategy is still abandonment, but a self-recrimination for the situation followed, demonstrating preoccupation with the self when experiencing a condition of being trapped or overwhelmed (Maier, 1956).

Ask a person in charge of the self-service registers to cancel the transaction and explain the reason. And come back some other time to be courteous to the people behind me and also the employee won't think that I was just being rude.

I would shrug with frustration because I was stupid enough to forget my money and hurriedly tell the clerk I don't want the stuff so that I could get out of the store quickly.

The asymptotic $\chi^{2}$ test of association (Table 4 ) with the four identified secondary resolution strategies (alteration, substitution, abandonment with acceptance and abandonment with suffering) and secondary blocks (anger, helplessness and self-preoccupation) showed significance $\left(\chi^{2}=13.71, d f=6\right.$, $p=0.033$ ) and provides support for H4. But because the test of association between the four identified secondary resolution strategies and secondary blocks had more than 20 per cent sparse cells, we conducted the Fisher's exact test (Baglivo et al., 1988), which was also significant $(p=0.031)$. To examine whether secondary resolution strategies associate with the social environment, a $\chi^{2}$ test of association was used for the four goal resolution strategies, and the three scenarios that manipulated the environment (Table 5) and showed significance $\left(\chi^{2}=12.26, d f=6\right.$, $p=0.056)$, thus supporting H5 and the idea that sociological influences combined with problem solving are related to the consumer's perceived situation. Because of sparse cells in the test for H5, Fisher's exact test was also run and yielded

Table 4. Goal resolution strategy by maladaptive-resignation response (Study 2)

\begin{tabular}{lccc}
\hline Resolution strategy & Anger & \multicolumn{2}{c}{ Helplessness Self-preoccupation } \\
\hline Alteration & $25(41.7 \%)$ & $28(44.4 \%)$ & $11(36.7 \%)$ \\
Substitution & $11(18.3 \%)$ & $3(4.8 \%)$ & $2(6.7 \%)$ \\
Abandon-acceptance & $18(30.0 \%)$ & $29(46.0 \%)$ & $17(56.7 \%)$ \\
Abandon-suffering & $6(10.0 \%)$ & $3(4.8 \%)$ & $0(0.0 \%)$ \\
\hline
\end{tabular}

Note: $\chi^{2}=13.71, d f=6, p=0.031$ (Fisher's exact test).
Table 5. Goal resolution strategy by social environment (Study 2)

\begin{tabular}{|c|c|c|c|}
\hline Resolution strategy & Alone & $\begin{array}{l}\text { With others: } \\
\text { unknown }\end{array}$ & $\begin{array}{l}\text { With others: } \\
\text { known }\end{array}$ \\
\hline Alteration & $14(34.1 \%)$ & $24(48.0 \%)$ & $26(41.9 \%)$ \\
\hline Substitution & $9(22.0 \%)$ & $1(2.0 \%)$ & $6(9.7 \%)$ \\
\hline $\begin{array}{l}\text { Abandon- } \\
\text { acceptance }\end{array}$ & $14(34.1 \%)$ & $22(44.0 \%)$ & $28(45.2 \%)$ \\
\hline $\begin{array}{l}\text { Abandon- } \\
\text { suffering }\end{array}$ & $4(9.8 \%)$ & $3(6.0 \%)$ & $2(3.2 \%)$ \\
\hline
\end{tabular}

Note: $\chi^{2}=12.26, d f=6, p=0.053$ (Fisher's exact test).

an improved, significant result over the asymptotic test $(p=0.053)$.

To examine the individual differences of frustration intolerance in relation to social environment, the 2 (frustration: high vs. low) $\times 3$ (social environment: alone vs. with others known vs. with others unknown) experimental design used a median split for level of frustration according to mean response to the FDS. With attitude toward the company and repatronage intention as dependent variables, a MANOVA was run for each of the four factors within the scale being used. The interaction between the entitlement and social environment was significant at the 0.10 level for attitude toward the company $(F=4.049, p=0.019)$ and repatronage intention $(F=2.788, p=0.065)$, as was the interaction between fairness and social environment for attitude toward the company $(F=2.406, p=0.094)$ and repatronage intention $(F=3.981$, $p=0.021)$. The interaction between gratification and social environment was significant for attitude toward the company $(F=2.705, p=0.070)$ but not repatronage intention ( $p$ $0.10)$. Finally, the interaction between achievement and social environment was not significant for repatronage intention or attitude toward the company (all $p \mathrm{~s}>0.10$ ). Therefore, results provide support for $\mathrm{H} 6, \mathrm{H} 7$ and $\mathrm{H} 9$, and partial support for H8 (Figures 1-5).

In addition, consumers high in entitlement had a more positive attitude toward the company when alone $(M=3.81)$ and less positive with people they did not know $(M=2.80)$. Those low in entitlement had their lowest attitude toward the company when alone $(M=3.15)$ and highest with others

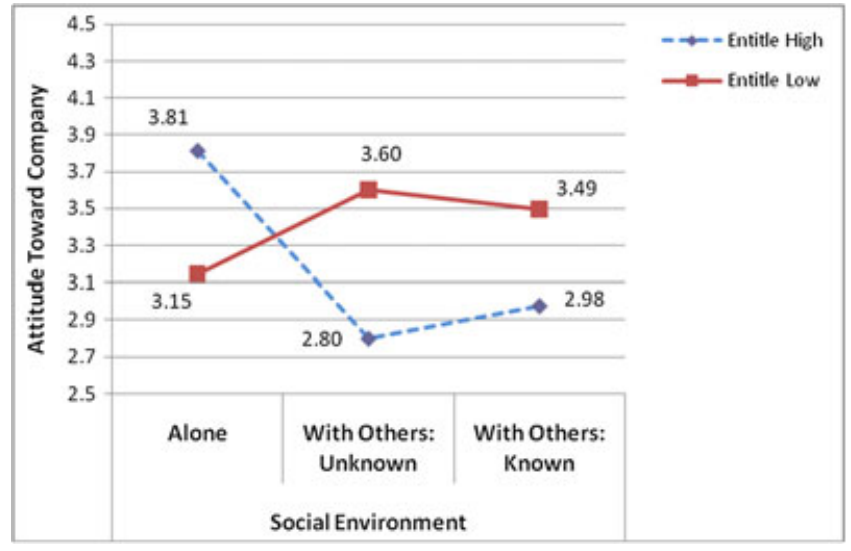

Figure 1. Social environment $\times$ frustration entitlement for attitude toward company. Note: Higher number means more favourable attitude. 


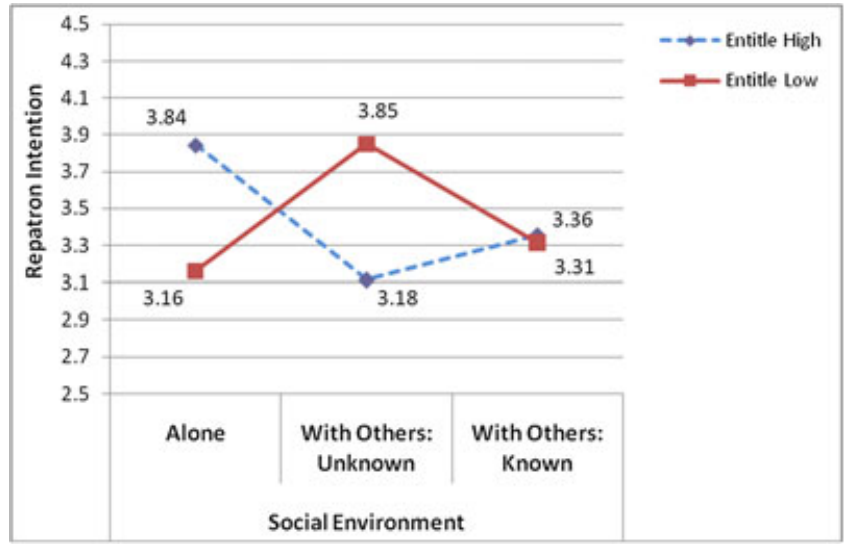

Figure 2. Social environment $\times$ frustration entitlement for repatronage intention. Note: Higher number means more likely repatronage.

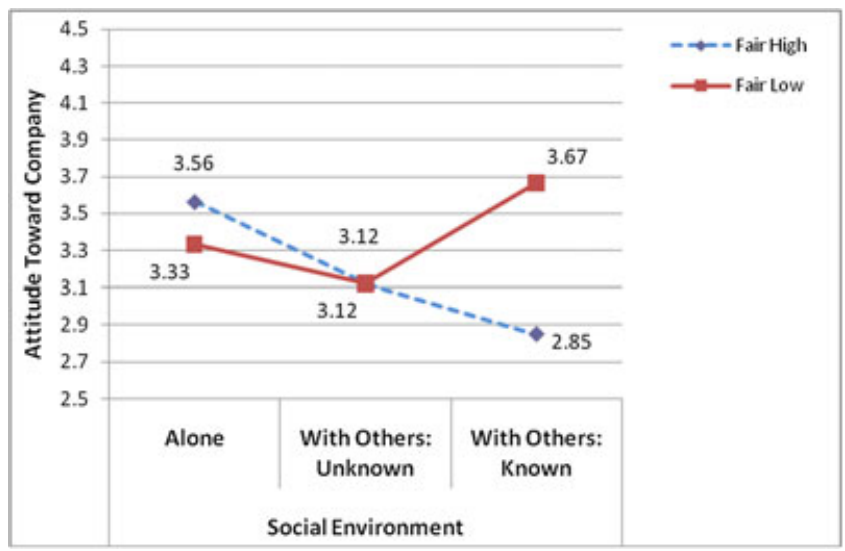

Figure 3. Social environment $\times$ frustration fairness for attitude toward the company. Note: Higher number means more favourable attitude.

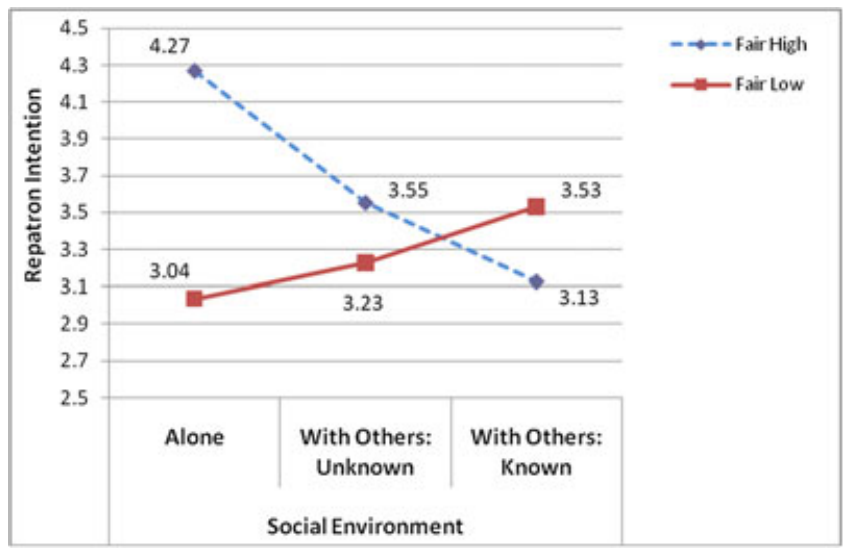

Figure 4. Social environment $\times$ frustration fairness for repatronage intention. Note: Higher number means more likely repatronage.

they did not know $(M=3.60)$. When with others they did know, individuals with a low sense of entitlement had a higher attitude toward the company than those with high entitlement $\left(M_{\text {low }}=3.49, M_{\text {high }}=2.98\right)$. Entitlement played a similar role on consumers in terms of repatronage intention. Those high in entitlement had their highest repatronage

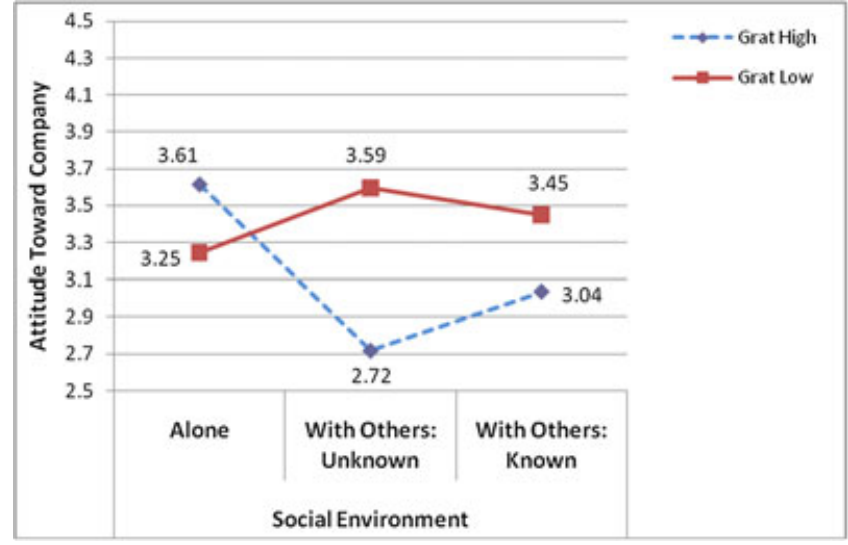

Figure 5. Social environment $\times$ frustration gratification for attitude toward the company. Note: Higher number means more favourable attitude.

intention when they were alone $(M=3.84)$ and lowest when they were with others they did not know $(M=3.18)$. Those low in entitlement were the opposite, but when with people they did know, there was virtually no difference between consumers low and high in entitlement $\left(M_{\text {low }}=3.36, M_{\text {high }}=3.31\right)$.

Fairness affected consumers differently, with those high in fairness showing the greatest change in their attitude toward the company when they were alone $(M=3.56)$ than with others they knew $(M=2.85)$, whereas those low in fairness reacted oppositely. Repatronage intention in terms of fairness shows it is extremely high for those high $(M=4.27)$ and much lower for those low in fairness $(M=3.04)$. That changed, however, when consumers were with people they knew, with those high in fairness having a higher repatronage intention than those who were lower $\left(M_{\text {high }}=3.55, M_{\text {low }}=3.13\right)$.

Consumers who were high in gratification experienced the most positive attitude toward the company when they were alone $(M=3.61)$ and least when they were with others they did not know $(M=2.72)$. Conversely, those who where low in gratification had their worst attitude when they were alone $(M=3.25)$ and best when they were with others they did not know $(M=3.59)$. Those low in gratification also had a better attitude toward the company when with people they did know than those who were high in gratification $\left(M_{\mathrm{low}}=3.45\right.$, $M_{\text {high }}=3.04$ ). The results provide additional confirmation for $\mathrm{H6}, \mathrm{H} 7$ and $\mathrm{H} 9$, and some support for $\mathrm{H} 8$.

Consumers who were high in entitlement and gratification exhibited more pro-retailer behaviour when they were alone than when they were with others, indicating that perhaps their reactions with an audience were just that, a performance to demonstrate and reinforce their privileged beliefs. Those low in entitlement and gratification adopted a more pro-social behaviour, perhaps in an effort to underscore their beliefs related to conspicuous consumption. This may also indicate that crowds of strangers in a retail setting can help mitigate frustration for some. Consumers were affected similarly by social situation in terms of fairness. The influence of social networking may be at play here, with the performance by both high- and low-fairness individuals changing their attitudes and loyalty between situations when they are alone and when they are with friends. 


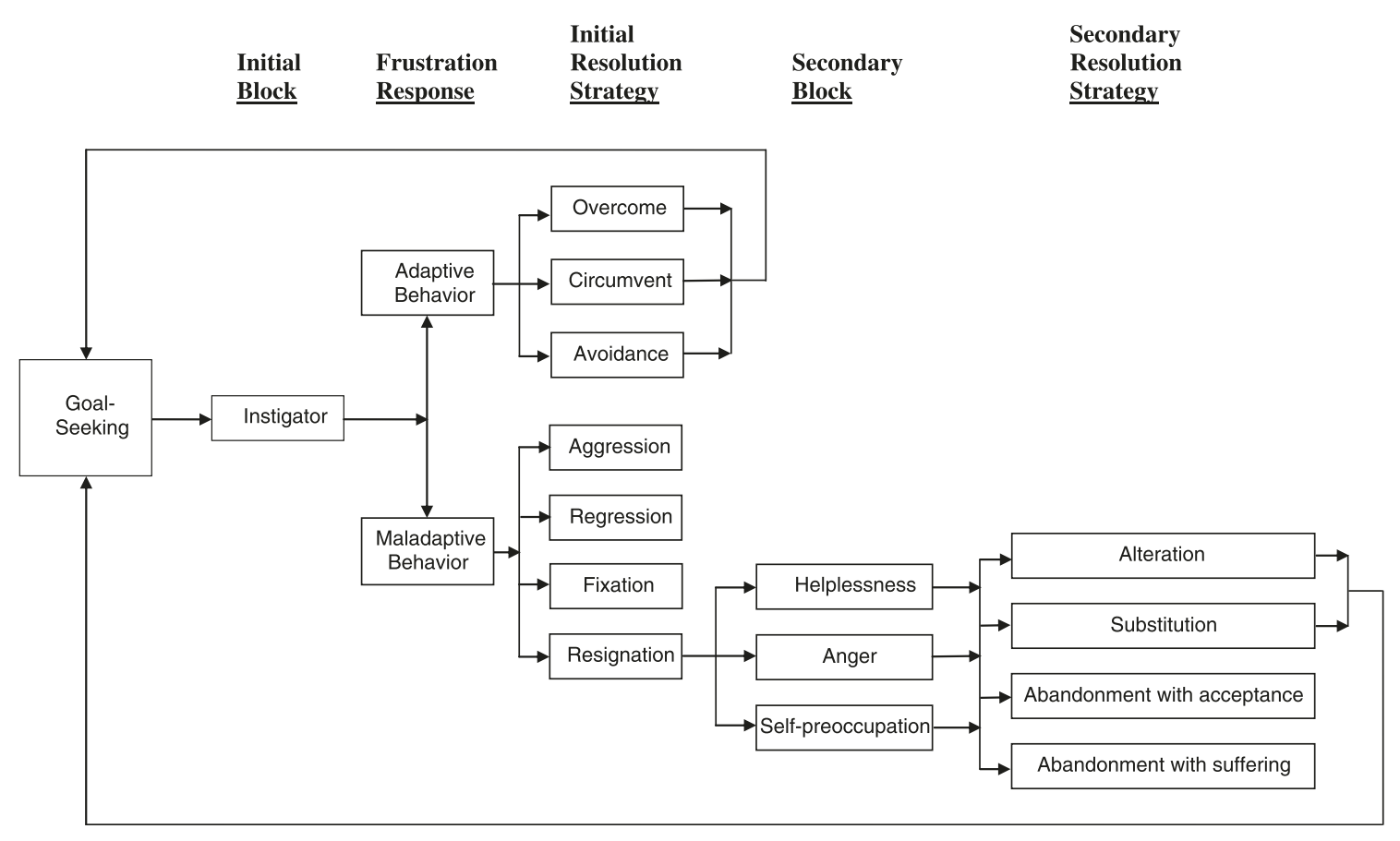

Figure 6. Model of frustration-initiated goal-directed sequence.

\section{DISCUSSION}

The present research contributes in multiple ways to understanding frustration when a consumer's goal is blocked. First, the study draws on precepts from frustration theory (Dollard et al., 1939; Barker et al., 1941; Block and Martin, 1955; Amsel, 1958, 1992; Shorkey and Crocker, 1981; Harrington 2005a, 2005 b) to identify a frustration-initiated goal-directed sequence of responses in such a retail context. Specifically, the research revealed that when the goal of retail checkout is blocked, consumers adopt either an adaptive or maladaptive resolution strategy. Those who take an adaptive approach return to goalseeking behaviour, whereas those following the maladaptive path initially resolve their frustrations through resignation (Figure 6). Subsequently, the second wave of blocks is countered with a second set of resolution strategies (alteration, substitution, abandonment with acceptance or abandonment with suffering). Further, the research contributes to our understanding of situational frustration in the face of blocked consumer goals with the finding that frustration responses are associated with source of blame, either internal or external, and social surroundings (i.e. who is watching the frustrating event). The present research enhances the literature on emotional response patterns by distinguishing frustration from anger in a consumer context (Strauss et al., 2005).

The second contribution pertains to our current understanding of the role of individual differences in responses to a thwarted consumer goal. In particular, the research demonstrated that individual differences in frustration tolerance, as measured by the FDS, are important factors in gauging consumers' reactions to a frustrating situation. The research also contributes to our understanding of the role played by entitlement, estimations of fairness, need for immediate gratification and need for achievement in a frustrating retail encounter.
Finally, the present investigation adds to our knowledge of key retailer attitudes with the finding that attitude toward the company and repatronage intentions are impacted by the social environment (who is watching) and individual differences in frustration tolerance (fairness, entitlement, gratification and achievement). An interesting contribution in this regard is the finding that social surroundings during checkout on consumers play an important role in influencing attitudes toward the store but is moderated by individual differences with respect to frustration.

\section{MANAGERIAL IMPLICATIONS}

Because customers are often motivated to shop by reasons unrelated to the product (Tauber, 1972), managers may attempt to increase value given by improving convenience and/or by completing transactions swiftly (Grace and O'Cass, 2005). When customers experience positive feelings toward the store, it influences their satisfaction and their repatronage intent (Jones and Reynolds, 2006). Guchait and Namasivayam (2012) found that frustration relates directly to unfair and unhelpful behaviours. Faced with frustrated customers, managers who wish to increase repatronage should create the most positive attitude toward their store possible (Korgaonkar et al., 1985) by evaluating whether the consumer believes he or she is being treated fairly. For consumers, the maladaptive behaviours stemming from the effects of resignation are rational because it is what they feel. Addressing these feelings should be the manager's first task because it can create what Lapidus and Pinkerton (1995) call a 'high-outcome situation'—one in which the customer is left with the feeling that their issues were resolved equitably. 
For example, when checkout queues are long, astute managers can assuage the helplessness stemming from their customers' feelings of entitlement and fairness - two factors that showed significance among consumers for both attitude toward the company and repatronage intention-by opening new queues. Because a company's management of queue waiting procedure is related to customer evaluations of service quality (Houston et al., 1998), employee training could include making sure customers who had been in the line the longest were serviced first, a managerial practice that effects customers' perception of social justice (Zhou and Soman, 2008).

Customers in the midst of a secondary block pose another difficulty for managers. Those who abandon (with acceptance or suffering) leave empty handed and will not repatronize the store because they believe the retailer does not care about them (Blodgett et al., 1993). Managers can turn this situation to their advantage by recognizing their customers' behaviour and engaging with positive reinforcement by directing them toward goal-substitution behaviour such as complimentary products or services on the present or future visit to the retail establishment. This was demonstrated specifically by one of the respondents in Study 2 who expected compensation from the retailer in the form of free food. The manager who can understand the problem, stand behind the product or service and 'make it right' may generate a loyal customer (Blodgett et al., 1993).

\section{LIMITATIONS AND FURTHER RESEARCH}

Although this study encompassed both qualitative and quantitative methods, it is still a first attempt at creating a model based on frustration theory, and problems with the generalizability of the findings may exist. Replication and verification are therefore needed. The focal context of the investigation was food shopping under pressure (hunger and time) suggestive of a utilitarian shopping endeavour. These findings should be further investigated through other focal contexts with a more hedonic orientation, such as fashion retailing. Maladaptive resolution strategies (particularly aggression) may be significant in other scenarios (Menon and Dubé, 2004; McColl-Kennedy et al., 2009) and deserve further investigation within the framework of frustration theory.

Future research could also examine the gap between what the consumer believes the retailer should do and what the consumer thinks the retailer will actually do. This 'customer-retailer expectation gap' is most relevant to practitioners who would do well to know what customers expect of them. Only two studies (Dornoff and Tankersley, 1975; 1981) examine this gap in frustration-based situations. Likewise, research should be designed to investigate the processes (mediators), which explain the frustration effect, rule out alternative predictions and/or explain some of the boundary conditions around consumer frustration tendency and response. Finally, the opportunity may exist to conduct inter-generational research based on how different cohorts respond to a frustrating situation. For example, Generation $\mathrm{Y}$ has a higher sense of entitlement (Harvey and Martinko, 2009) and is accustomed to, and demands, immediate gratification (Arhin and Johnson-Mallard, 2003; Polimeni et al., 2009) - two of the FDS dimensions that this research found were related to attitude toward the company and repatronage intention-and therefore may generate different responses than their Baby Boomer parents or Generation X, which sits between the two.

The use of frustration theory in a retail context holds much promise for both academic research and managerial application in terms of recognizing problems in a retail setting and responding accordingly to increase customer satisfaction and loyalty. It would be beneficial to continue research in this regard in an attempt to develop marketing strategies that help avert or avoid consumer frustration.

\section{BIOGRAPHICAL NOTES}

Eric Van Steenburg, PhD, Visiting Assistant Professor at James Madison University, Harrisonburg. His research interests include nonprofit marketing, political marketing, consumer behaviour and persuasive communications. He has published in the Journal of Product and Brand Management, Journal of Brand Management, Journal of Political Marketing, Journal of Promotion Management and numerous conference proceedings.

Nancy Spears, $\mathrm{PhD}$, is an Associate Professor at the University of North Texas, Denton. Her research interests are in the area of consumer behaviour, sales promotion and analysis of socio-historical trends in advertising. She has published in journals such as the Journal of Advertising, Journal of Consumer Psychology, Psychology \& Marketing, Journal of Customer Behaviour, Journal of Business Research and the Journal of Current Issues \& Research in Advertising.

Robert O. Fabrize, $\mathrm{PhD}$, is an Assistant Professor in the International Business \& Marketing Department at California State Polytechnic University, Pomona. His research focuses on consumer behaviour, particularly on the self, metaphor and nonconscious processing. He has previously published in the proceedings of the AMA Summer and Winter Educators' Conferences, and the AMS Annual Conference.

\section{REFERENCES}

Arhin AO, Johnson-Mallard V. 2003. Encouraging alternative forms of self expression in the Generation Y student: a strategy for effective learning in the classroom. The ABNF Journal 14(6): 121-122.

Alpert R, Haber RN. 1960. Anxiety in academic achievement situations. Journal of Abnormal and Social Psychology 61(2): 207-215.

Amsel A. 1958. The role of frustrative nonreward in noncontinuous reward situations. Psychological Bulletin 55(2): 102-119.

Amsel A. 1962. Frustrative nonreward in partial reinforcement and discrimination learning: some recent history and a theoretical extension. Psychological Review 69(4): 306-328.

Amsel A. 1992. Frustration Theory. An Analysis of Dispositional Learning and Memory. Cambridge University Press: New York.

Anderson CA, Buschman BJ. 2002. Human aggression. Annual Review of Psychology 53(1): 27-51.

Barker R, Dembo T, Lewin K. 1941. Frustration and Regression. An Experiment with Young Children. University of Iowa Press: Iowa City.

Berkowitz L. 1989. Frustration-aggression hypothesis: examination and reformulation. Psychological Bulletin 106(1): 59-73.

Bernard HR, Ryan GW. 2010. Analyzing Qualitative Data: Systematic Approaches. Sage Publications: Los Angeles. 
Baglivo J, Olivier D, Pagano M. 1988. Methods for the analysis of contingency tables with large and small cell counts. Journal of the American Statistical Association 83 (404): 1006-1013.

Block J, Martin B. 1955. Predicting the behaviour of children under frustration. Journal of Abnormal and Social Psychology 5(2): 281-285.

Blodgett JG, Granbois DH, Walters RG. 1993. The effects of perceived justice on complainants' negative word-of-mouth behaviour and repatronage intentions. Journal of Retailing 69(4): 399-428.

Bolton RN, Kannan PK, Bramlett MD. 2000. Implications of loyalty program membership and service experiences for customer retention and value. Journal of Marketing Science 28(1): 95-108.

Borges NJ, Manuel RS, Elam CL, Jones BJ. 2010. Differences in motives between Millennial and Generation X medical students. Medical Education 44(6): 570-576.

Butterfield EC. 1964. Locus of control, test anxiety, reactions to frustration, and achievement attitudes. Journal of Personality 32(3): 355-370.

Coleman AM. 2001. A Dictionary of Psychology. Oxford University Press: New York.

Dollard J, Miller NE, Doob LW, Mowrer OH, Sears RS. 1939. Frustration and Aggression. Yale University Press: New Haven.

Dornoff RJ, Tankersley CB. 1975. Perceptual differences in market transactions: a source of consumer frustration. Journal of Consumer Affairs 9(1): 97-103.

Dornoff RJ, Tankersley CB. 1981. Perceptual differences in market transactions: a waning source of consumer frustration. Journal of Consumer Affairs 15(1): 146-157.

Funder DC, Block J. 1989. The role of ego-control, ego-resiliency, and IQ in delay of gratification in adolescence. Journal of Personality and Social Psychology 57(6): 1041-1050.

Freud S. 1958. Types of onset of neurosis. in The Standard Edition of the Complete Psychological Works of Sigmund Freud vol. 12, J Strachey (ed.). Hogarth Press: London; 227-230.

Freund RJ, Wilson WJ. 1993. Statistical Methods. Harcourt Brace Jovanovich, Publishers: Boston.

Goldsmith RE, Lafferty BA, Newell SJ. 2001. The impact of corporate credibility and celebrity credibility on consumer reaction to advertisements and brands. Journal of Advertising 29(3): 30-54.

Grace D, O'Cass A. 2005. An examination of the antecedents of repatronage intentions across different retail store formats. Journal of Retailing and Consumer Services 12(4): 227-243.

Guchait P, Namasivayam K. 2012. Customer creating of service products: role of frustration in customer evaluations. Journal of Services Marketing 26(3): 216-224.

Gutman J. 1997. Means-end chains as goal hierarchies. Psychology and Marketing 14(6): 545-560.

Gelbrich K. 2009. Beyond just being dissatisfied. How angry and helpless consumers react to failures when using self-service technologies. Schmalenbach Business Review 61(1): 40-59.

Harrington N. 2005a. The frustration discomfort scale: development and psychometric properties. Clinical Psychology \& Psychotherapy 12(5): 374-387.

Harrington N. 2005b. Dimensions of frustration intolerance and their relationship to self-control problems. Journal of RationalEmotive and Cognitive-Behaviour Therapy 23(1): 1-19.

Harvey P, Martinko MJ. 2009. An empirical examination of the role of attributions in psychological entitlement and its outcomes. Journal of Organizational Behaviour 30: 459-476.

Hill WF. 1968. Theoretical note: an attempted clarification of frustration theory. Psychological Review 75(2): 173-176.

Houston MB, Bettencourt LA, Wegner S. 1998. The relationship between waiting in a service queue and evaluations of service quality: a field theory perspective. Psychology and Marketing 15(8): 735-753.

Hurst JL, Good LK. 2009. Generation Y and career choice: the impact of retail career perceptions, expectations and entitlement perceptions. Career Development International 14(6): 570-593.
Jones MA, Reynolds KE. 2006. The role of retailer interest on shopping behaviour. Journal of Retailing 82(2): 115-126.

Korgaonkar PK, Lund D, Price B. 1985. A structural equations approach toward examination of store attitude and store patronage behaviour. Journal of Retailing 61(2): 39-60.

Lapidus RS, Pinkerton L. 1995. Customer complaint situations: an equity theory perspective. Psychology and Marketing 12(2): 105-122.

Laros FJM, Steenkamp JEM. 2005. Emotions in consumer behavior: a hierarchical approach. Journal of Business Research 58(10): 1437-1445.

Lawler EJ. 2001. An affect theory of social exchange. The American Journal of Sociology 107(2): 321-352.

Lazarus RS. 1991. Emotion and Adaptation. Oxford University Press: New York.

Levis DJ. 1976. Learned helplessness: a reply and an alternative S-R interpretation. Journal of Experimental Psychology 105 (1): 47-65.

Maier NRF. 1956. Frustration theory: restatement and extension. Psychological Review 63(6): 370-388.

Maier NRF, Ellen P. 1959. The integrative value of concepts in frustration theory. Journal of Consulting Psychology 23(3): 195-206.

Maier NRF, Feldman RS. 1948. Studies of abnormal behaviour in the rat. XXII. Strength of fixation and duration of frustration. Journal of Comparative and Physiological Psychology 41(5): 348-363.

Maier NRF, Seligman MEP. 1976. Learned helplessness: theory and evidence. Journal of Experimental Psychology 105(1): 3-46.

Martin RC, Dahlen ER. 2004. Irrational beliefs and the experience and expression of anger. Journal of Rational-Emotive and Cognitive-Behaviour Therapy 22(1): 3-20.

Mattila AS, Wirtz J. 2004. Consumer complaining to firms: the determinants of channel choice. Journal of Services Marketing 18(2): 147-155.

McColl-Kennedy JR, Patterson PG, Smith AK, Brady MK. 2009. Customer rage episodes: emotions, expressions and behaviours. Journal of Retailing 85(2): 222-237.

Menon K, Dubé L. 2007. The effect of emotional provider support on angry versus anxious consumers. International Journal of Research in Marketing 24(3): 268-275.

Menon K, Dubé L. 2004. Service provider responses to anxious and angry customers: different challenges, different payoffs. Journal of Retailing 80(3): 229-237.

Nation JR, Massad P. 1978. Persistence training: a partial reinforcement procedure for reversing learned helplessness and depression. Journal of Experimental Psychology 107(4): 436-451.

Nation JR, Woods DJ. 1980. Persistence: the role of partial reinforcement in psychotherapy. Journal of Experimental Psychology 109(2): 175-207.

Naumann SE, Minsky BD, Sturman MC. 2002. A historical examination of employee entitlement. Management Decision 40(1): 89-94.

Noble SM, Haytko DL, Phillips J. 2009. What drives college-age Generation Y consumers? Journal of Business Research 62(6): 617-628.

Nyer PU. 2000. An investigation into whether complaining can cause increased consumer satisfaction. Journal of Consumer Marketing 17(1): 9-19.

Nyer PU. 1997. A study of the relationships between cognitive appraisals and consumption emotions. Journal of the Academy of Marketing Science 25(4): 296-304.

O'Donoghue T, Rabin M. 2000. The economics of immediate gratification. Journal of Behavioural Decision Making 13(2): 233-250.

Pincus J. 2004. The consequences of unmet needs: the evolving role of motivation in consumer research. Journal of Consumer Behaviour 3(4): 375-387.

Polimeni RS, Burke JA, Benyaminy D. 2009. Using computer simulations to recruit and train Generation $\mathrm{Y}$ accountants. Development and Learning in Organizations 23(6): 64-68.

Rosellini RA, Seligman MEP. 1975. Frustration and learned helplessness. Journal of Experimental Psychology 1(2): 149-157. 
Roseman IJ. 1991. Appraisal determinants of discrete emotions. Cognition and Emotion 5(3): 161-200.

Rosenzweig S. 1934. Types of reaction to frustration. Journal of Abnormal and Social Psychology 29(3): 298-300.

Scherer KR. 2001. Appraisal considered as a process of multilevel sequential checking. In Appraisal Process in Emotion, Scherer KR, Schorr A, Johnstone T. (eds). Oxford University Press: New York; 92-120.

Shorkey CT, Crocker SB. 1981. Frustration theory: a source of unifying concepts for generalist practice. Social Work 26(5): 374-379.

Smith CA, Ellsworth PC. 1985. Patterns of cognitive appraisal in emotion. Journal of Personality and Social Psychology 48(5): 813-838.

Smith CA, Lazarus RS. 1990. Emotion and adaptation. In Handbook of Personality: Theory and Research, Pervin LA (ed.), Guilford Press: New York; 609-637.

Smith CP, Ryan ER, Diggins DR. 1972. Moral decision making: cheating on examinations. Journal of Personality 40(4): 640-660.

Snow JN, Kern RM, Curlette WL. 2001. Identifying personality traits associated with attrition in systematic training for effective parenting groups. The Family Journal: Counseling and Therapy for Couples and Families 9(2): 102-108.

Soderlund M. 2003. Behind the satisfaction façade: an exploration of customer frustration. Proceedings of the 32nd EMAC, Glasgow, 20-23 May.

Stiles WB. 1987. I have to talk to somebody: a fever model of disclosure. In Theory, Research and Therapy, Derlega VJ, Berg JH (eds). Plenum Press: New York; 257-282.

Strauss B, Schmidt M, Schoeler A. 2005. Customer frustration in loyalty programs. International Journal of Service Industry Management 16(3): 229-252.

Tauber EM. 1972. Why do people shop? Journal of Marketing 36 (4): 46-49.
Tedeschi JT, Felson RB. 1994. Violence, Aggression, and Coercive Actions. American Psychological Association: Washington, D.C.

Turner JH, Stets JE. 2006. Sociological theories of human emotions. Annual Review of Sociology 32: 25-52.

Tuzovic S. 2010. Frequent (flier) frustration and the dark side of word-of-web: exploring online dysfunctional behaviour in online feedback forums. Journal of Services Marketing 24(6): 446-457.

Van den Bos K. 2001. Uncertainty management: the influence of uncertainty salience on reactions to perceived procedural fairness. Journal of Personality and Social Psychology 80(6): 931-941.

Van den Bos K, Lind EA, Vermunt T, Wilke HAM. 1997. How do I judge my outcome when I do not know the outcome of others? Journal of Personality and Social Psychology 72(5): 1034-1046.

Verhallen TMM. 1982. Scarcity and consumer choice behaviour. Journal of Economic Psychology 2: 299-321.

Wagner AR. 1963. Conditioned frustration as a learned drive. Journal of Experimental Psychology 66(2): 142-148.

Weiner B. 1986. An Attributional Theory of Motivation and Emotion. Springer: New York.

Wellner AS. 2004. Spoiled brats: your HR policies may be contributing to a sense of employee entitlement. HR Magazine 49(11): 60-66.

Wetzer IM, Zelenberg M, Pieters R. 2007. Never eat in that restaurant, I did! Exploring why people engage in negative word-of-mouth communication. Psychology and Marketing 24 (8): 661-680.

Yi S, Baumgartner H. 2004. Coping with negative emotions in purchaserelated situations. Journal of Consumer Psychology 14(3): 303-317.

Zhou R, Soman D. 2008. Consumers' waiting in queues: the role of first-order and second-order justice. Psychology and Marketing 25(): 262-279. 